\title{
Effect of the Ethanolic Extract of Khaya senegalensis on Some Biochemical Parameters on Rabbit's in Glucose Overload Condition
}

\author{
Essé Agossou1, Mélanie Ahokpe1, Justin Behanzin1, Marcellin Takin', Ganiou Yessoufou1, \\ Loica Zohoun', Lamine Baba-Moussa², Alphonse Sezan ${ }^{1 *}$ \\ ${ }^{1}$ Laboratoire de Biomembranes et Signalisation Cellulaire Département de Physiologie Animale, Université \\ d'Abomey-Calavi, Cotonou, Benin \\ ${ }^{2}$ Laboratoire de Biologie et de Typage moléculaire en Microbiologie Département de Biochimie et de Biologie \\ Cellulaire, Université d'Abomey Calavi, Cotonou, Benin \\ Email: sezco@live, ${ }^{*}$ alphonse.sezan@fast.uac.bj
}

Received 5 January 2015; accepted 22 January 2015; published 26 January 2015

Copyright (C) 2015 by authors and Scientific Research Publishing Inc.

This work is licensed under the Creative Commons Attribution International License (CC BY). http://creativecommons.org/licenses/by/4.0/

(c) (i) Open Access

\section{Abstract}

The effect of the ethanolic extract Khaya senegalensis on some biochemical parameters was tested in rabbits with normal glucose and glucose overload. Phytochemical screening after three batches of 6 rabbits race (TBD) were treated with the extract in oral doses of respectively 10, 25 and 50 $\mathrm{mg} / \mathrm{kg}$ body weight for 30 days; three other groups receiving respectively these doses of the extract were placed under a priori temporary overload of glucose; a control group received instead distilled water treatment. Blood glucose, triglycerides and total cholesterol were measured by spectrophotometry and weight gain of the animals was performed at the beginning of the experiment and every 2 weeks during the study period. The phytochemical screening revealed the presence of polyphenolic compounds (majority) of saponins of anthracene derivatives and steroids in the extract. The test results indicate that under the dose of $50 \mathrm{mg} / \mathrm{kg}$ body weight (BW) there was a significant decrease $(p<0.05)$ in blood glucose after 24 hours. The extract had no effect on the lipid profile or body weight of rabbits.

\section{Keywords}

Rabbit, Khaya senegalensis, Glucose, Lipid Profile

\footnotetext{
${ }^{*}$ Corresponding author.
}

How to cite this paper: Agossou, E., Ahokpe, M., Behanzin, J., Takin, M., Yessoufou, G., Zohoun, L., Baba-Moussa, L. and Sezan, A. (2015) Effect of the Ethanolic Extract of Khaya senegalensis on Some Biochemical Parameters on Rabbit's in Glucose Overload Condition. American Journal of Plant Sciences, 6, 240-248. http://dx.doi.org/10.4236/ajps.2015.61027 


\section{Introduction}

The use of bioactive plant became popular more particularly in poor regions such as Africa and Asia [1] in the treatment of chronic diseases [2]-[5]. The use of these plants does not guarantee full effectiveness and safety [6]. The risk of toxicity associated with chemical compounds of medicinal plants becomes the concern of Scientific Research [7]. Khaya senegalensis (Meliaceae), a tropical plant, is widely used for its therapeutic properties. It is used in the treatment of malaria, jaundice etc. [8]. The seeds and leaves of Khaya s. are used in the treatment of fever and headache [9], amenorrhea, smallpox, jaundice, lumbago and rheumatism whereas extracts of roots treat mental illness, leprosy and syphilis [9]. Many scientific studies have demonstrated the biological activity of extracts of Khaya senegalensis, aqueous extracts and ethyl showed biological activity in rats through effects on biochemical and hematological parameters [10] [11], as it has been shown that extracts of Khaya s. possess antiradical activity [12]. Based on these results, it remains that the safety of this plant is to prove. On suspicion of an impact of Khaya s. on metabolism, we studied the effect of the ethyl extract of Khaya senegalensis on blood glucose and blood lipid profile in rabbits.

\section{Materials and Methods}

The study was conducted at the Laboratory of Biomembranes and Cell Signaling, Faculty of Sciences and Techniques, University of Abomey Calavi, south of Benin, between July 2011 and March 2012. The extraction were performed at the Laboratory of Pharmacognosy and Essential Oils at the Institute of Applied Biomedical Sciences (ISBA), Cotonou, Benin.

Plant material. The barks of Khaya senegalensis were collected in July 2011 in the town of Abomey Calavi, agro-ecological zone VI, in southern Benin. This area has a climate Guinean type with two rainy seasons (AprilJuly, September-November) rainfall varies from 1000 to $1400 \mathrm{~mm}$ and the soil is lateritic, ferruginous or hydro morph. The plant material was air-dried and milled into powder [3].

\subsection{Preparation of Extract}

Dry bark of Khaya senegalensis were cut into small pieces and then ground in mill knives. $100 \mathrm{~g}$ of the resulting powder, weighed using an analytical balance Sartorius ${ }^{\circledR}$ and placed in a jar prepared for this purpose, were soaked in $500 \mathrm{ml}$ of $96 \%$ ethanol for 72 hours. Then the macerate was filtered through cotton wool fiber. The obtained filtrate was evaporated at $40^{\circ} \mathrm{C}$ using the evaporator ROTAVAPOR ${ }^{\circledR}$. The paste deposited at the bottom of the evaporator ball was recovered in jars and put to dry in an oven at $45^{\circ} \mathrm{C}$. After complete drying, the solids fused to the bottom of the jars were scraped, crushed and kept in jars.

\subsection{Biological Material}

Twenty-four rabbits (Oryctolagus cuniculus) of body weight between 1.155 and $1.370 \mathrm{~kg}$, provided by the animal production department of the University of Abomey Calavi were used for the test.

The 24 rabbits were fed exclusively on fodder and water to drink, and they received no other medication at the time outside of the extract. They were randomly divided into three groups of 06 rabbits treated as follows:

-Lot 1 (L1) was the control group receiving oral administration of distilled water in place of ethyl extract of Khaya senegalensis,

-Lot 2 (L2) was the group treated by oral administration at a dose of $10 \mathrm{mg} / \mathrm{kg}$ body weight/day of ethyl extract of Khaya senegalensis, for 15 days.

-Lot 3 (L3) was the group treated by oral administration at a dose of $25 \mathrm{mg} / \mathrm{kg}$ body weight/day of ethyl extract of Khaya senegalensis, for 15 days.

-Lot 4 (L4) was batch treated by oral administration at a dose of $50 \mathrm{mg} / \mathrm{kg}$ body weight/day of ethyl extract of Khaya senegalensis, for 15 days.

\subsection{Phytochemical Screening}

It is based on the reactions (color and precipitation) Differential major groups of chemical compounds in plants according to the method of Houghton PJ and A. RAMAN (1998) [13] reviewed and adapted to the conditions of the Laboratory of Pharmacognosy and Essential Oils of ISBA. 


\subsection{Determination of Biochemical Parameters}

To assay blood glucose, triglycerides and cholesterol in rabbits, we collected vacuum blood of these animals from the marginal ear vein, and the blood is collected in dry test tubes (for triglycerides and cholesterol) and anticoagulant (EDTA for glucose), and is then centrifuged at $3000 \mathrm{rpm}$ for 5 minutes and the supernatant serum or plasma were decanted and stored for the determination of these parameters.

\subsubsection{Glucose}

We measured blood glucose by the enzymatic method with GOD-PAP reagent ${ }^{\circledR}$ (Bio Lab Lot: 021101A/2013/ 02 SCI) with T0, T0 + 6 hours, 12 hours and T0 +18 hours, 24 hours T0, T0 + 15 days and 30 days, T0 corresponds to the sampling time at the end of 12 hours of fasting before administration of distilled water and ethyl extract of Khaya senegalensis.

Trinder method: In aqueous medium and in the presence of oxygen, glucose oxidase (GOD) catalyses the oxidation of glucose to gluconic acid and hydrogen peroxide $\left(\mathrm{H}_{2} \mathrm{O}_{2}\right)$ in the reaction.

Glucose $+1 / 2 \mathrm{O}_{2}+2 \mathrm{H}_{2} \mathrm{O}+\mathrm{H}_{2} \mathrm{O}_{2}$ gluconic acid

In the presence of peroxidase (POD), hydrogen peroxide reacts with 4-chloro-phenol and 4-aminoantipyrine (PAP) which is colorless in the reduced state to form a quinoneimine. Quinoneimine formed has a pink color whose intensity is proportional to the glucose concentration. This intensity is measured with a spectrophotometer at $500 \mathrm{~nm}[4][5]$.

\subsubsection{Triglycerides}

Kit BIOLABO TRIGLYCERIDES GPO lot 071106B method of ref 80019 is used to determine blood levels trigycérides.

The assay principle is based on the method and Fossati Prencipe coupled to a Trinder reaction: the triglycerides are hydrolyzed enzymatically by lipase to free fatty acids and glycerol. The glycerol is phosphorylated by adenosine triphosphate (ATP) and glycerol kinase (GK) to produce glycerol-3-phosphate and adenosine diphosphate (ADP). Glycerol-3-phosphate is oxidized to dihydroxyacetone phosphate (DAP) with glycerol phosphate oxidase (GPO) to produce hydrogen peroxide $\left(\mathrm{H}_{2} \mathrm{O}_{2}\right)$. In a color reaction catalyzed by peroxidase, $\mathrm{H} 2 \mathrm{O} 2$ reacts with 4-aminoantipyrine (PAP) and 4-chlorophenol ((4-CP) to produce quinoneimine (pink) and water. Reaction scheme is as follows:

LIPASE Triglycerides Glycerol + free fatty acids

GK Glycerol + ATP glycerol-3-phosphate + ADP

Glycerol-3-phosphate Dihydroxyacetone phosphate $+\mathrm{O}_{2}+\mathrm{H}_{2} \mathrm{O}_{2}$ GPO

$\mathrm{H}_{2} \mathrm{O}_{2}+4$-chlorophenol + PAP quinoneimine POD (pink) $+\mathrm{H}_{2} \mathrm{O}$

The absorbance of the colored complex (quinoneimine), proportional to the concentration of triglycerides in the serum sample is measured at $500 \mathrm{~nm}$ [5] [7].

$\mathrm{H}_{2} \mathrm{O}_{2}+4$-chloro-phenol +4 -aminoantipyrine $+4 \mathrm{H}_{2} \mathrm{O}$ quinoneimine

\subsubsection{Total Cholesterol}

Kit BIOLABO CHOLESTEROL CHOD-PAP lot 081104A REF 80106 was used.

The principle of the assay is as follows: cholesterol was determined using the CHOD-PAP enzymatic method described by Allain et al. [14], According to the following scheme:

$\mathrm{EC}+$ esterified cholesterol Cholesterol Free fatty acids

Cholesterol $+\mathrm{O}_{2}$ CO cholestene-4-one- $3+\mathrm{H}_{2} \mathrm{O}_{2}$

$2 \mathrm{H}_{2} \mathrm{O}_{2}+$ Phenol +4 -aminoantipyrine $+4 \mathrm{H}_{2} \mathrm{O}$ POD quinoneimine

Quinoneimine formed has a pink color whose intensity is proportional to the amount of cholesterol present in the serum sample [6]. This intensity is measured with a spectrophotometer at $500 \mathrm{~nm}$.

\subsubsection{Data Processing}

The data are processed in the Microsoft Office 2007 software Minitab14 2003 version was used for the different tests comparing average, the T-test was used for comparison of means of biochemical parameters between different batches of rabbits and for changes in biochemical parameters in time to appreciate the statistical significance of the difference of parameters between different batches of rabbits, we used analysis of variance (one-way 
\pm ANOVA). The parameter results are expressed as mean standart deviation.

\section{Results and Discussions}

The screening phytochimic, of the ethanolic extracts of Khaya senegalensis, shows the presence of several molecules. These molecules and their presence rates in the extracts are listed in Table 1.

Weighed the on different ones periods (T0: beginning of the experiment; " $\mathrm{T}+15$ ": 15 days after the beginning of the experiment; and " $\mathrm{T}+30$ ": 30 days after the beginning of the experiment) of rabbits separated in 4 batches (L50 mg, L25 mg, L10 mg, L0 mg) according to the amount from extracts which was managed to them, showed a variation of weight in the rabbits which is listed in Table 2.

The impact on the glycemia of the administration to rabbits of the various amounts of extracts of Khaya senegalensis, measured according to time, shows on Figure 1 a weak variation of the glycemia with regard to the pilot batch and the batches of the amounts: L25 mg, L10 mg. While for rabbits of the batches of amount: L50 $\mathrm{mg}$, a fall of the glycemia is observed during the first 15 days of the experiment, then it goes up Until the 30th day of experiment.

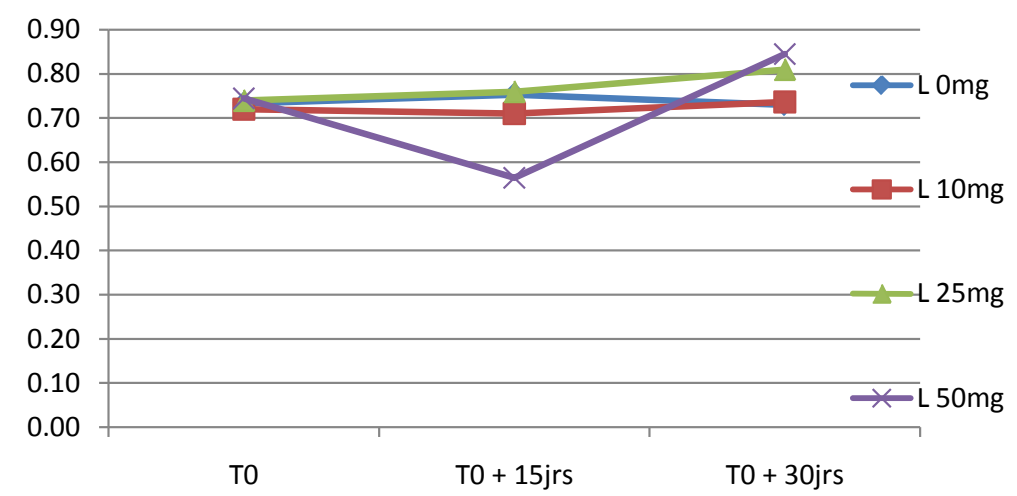

Figure 1. Variation of glucose under the influence of different doses of K.S. function of time.

Table 1. Phytochemical screening of ethanolic extracts of Khaya senegalensis.

\begin{tabular}{ccc}
\hline Chemical groups & Subgroups & Observation \\
\hline & Tannins & +++ \\
Polyphénolics & Catechin tannins & +++ \\
& Anthocyanin & ++ \\
Saponins & Leuco-anthocyanin & ++ \\
Steroids & Saponosides Foam index 4 & ++ \\
Anthracene derivatives & Steroids & + \\
\hline
\end{tabular}

+++: Abondant; ++: not abundant; +: low.

Table 2. Weight of rabbit's normoglycemic versus time.

\begin{tabular}{cccc}
\hline & \multicolumn{3}{c}{ Times (days) } \\
\hline Doses & T0 & $\mathrm{T}+15$ days & $\mathrm{T}+$ days \\
L0 mg & $0.93 \pm 0.23$ & $1.47 \pm 0.27$ & $1.53 \pm 0.14$ \\
L10 $\mathrm{mg}$ & $1.15 \pm 0.41$ & $1.49 \pm 0.09$ & $1.63 \pm 0.06$ \\
L25 mg & $1.03 \pm 0.18$ & $1.6 \pm 0.25$ & $1.79 \pm 0.23$ \\
L50 mg & $0.97 \pm 0.03$ & $1.54 \pm 0.20$ & $1.65 \pm 0.21$ \\
\hline
\end{tabular}


The impact on the glycemia of the administration to rabbits of the various amounts of extracts of Khaya senegalensis, measured at different hours on 24 hours, does not show any variation of the glycemia on Figure 2 with regard to the pilot batch over all the duration of the experiment for the batches of the amounts: $\mathrm{L} 25 \mathrm{mg}, \mathrm{L}$ $50 \mathrm{mg}$, a growth of the glycemia is observed over the first 6 hours of the experiment. This glycemia fall the 6 hours following, is stabilized 12th hour per 18th hour then falls until the end of the experiment. While for rabbits of the batches of amount: L10 mg, a weak growth of the glycemia is observed during the first 6 hours of the experiment, the slope of growth increases and the glycemia is stabilized to leave per 12th hour the experiment and starts to fall per 18th hour of the experiment.

The impact on the glycemia of the administration to rabbits in temporary hyperglycemia of the various amounts of extracts of Khaya senegalensis, measured at different hours, shows on Figure 3 a fall of the glycemia for the $2 \mathrm{~h}$ before the beginning of the experiment. It is necessary noted that the fall of the glycemia lose the batch of L50 mg amount is weak, while it is significant for the other batches.

The impact on the triglyceridemy of the administration to rabbits of the various amounts of extracts of Khaya senegalensis, measured according to time, shows on Figure 4 a growth of this triglyceridemy hanging the 15 following days the beginning of this experiment. From the 15th day it falls until the 30 e day with regard to the batch of amount L10 mg. For the batches of L0 mg amounts and $50 \mathrm{mg}$, a weak growth is observed all along the experiment. Finally for the batch L25 mg weak a growth of the triglyceridemy is observed the first 15 days of the experiment, this growth increases until the 30 e days.

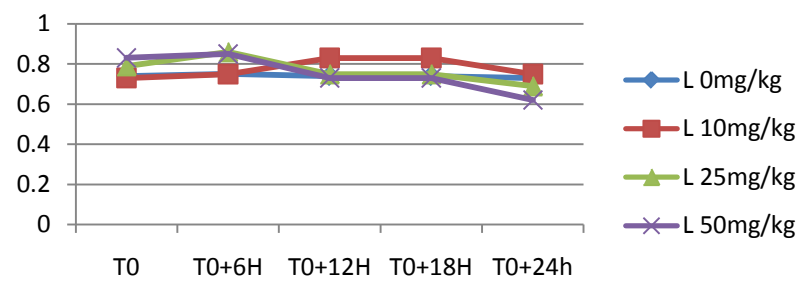

Figure 2. Variation in blood glucose under influence of different doses of K.S. in 24 hours.

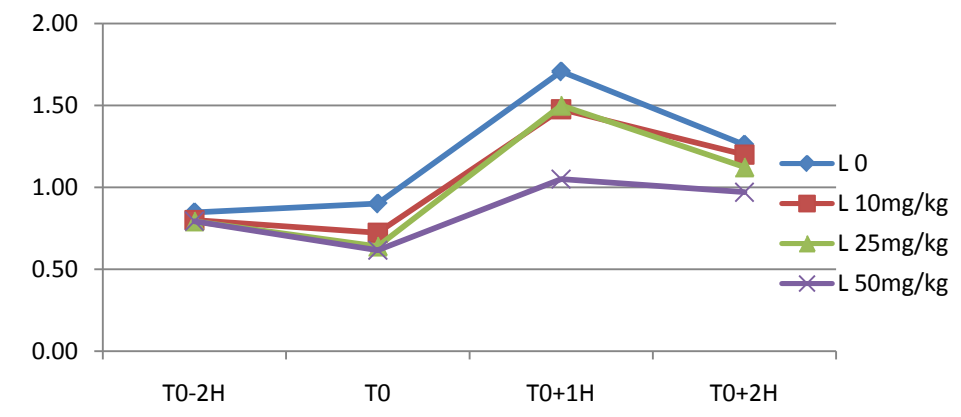

Figure 3. Variation in blood glucose under influence of different doses of K.S. in temporary hyperglycemia.

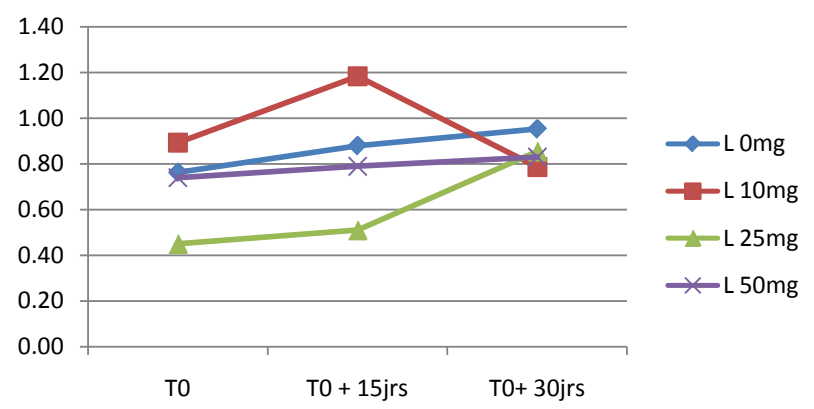

Figure 4. Triglycerides variation under influence of different doses of K.S. versus time. 
The variation all the 6 hours of the triglyceridemy of hanging rabbits under influences $24 \mathrm{~h}$ of the different amounts of extracts of Khaya senegalensis is illustrated on Figure 5. For all the amounts one observes a weak fall of this triglyceridemy during the first 6 hours of the experiment, then a significant growth of this trygliceridemy with regard to the batch of L25 mg amount, until the 12th hour for the other batches this growth is weak. After the trygliceridemy is stabilized for the batches L25 mg and L50 mg and a weak fall slightly for the other batches until the 18th $\mathrm{h}$. And finally a progressive fall for all the batches until the end of the experiment.

The triglyceridemy of rabbits in temporary hyperglycemia and under influences of the various amounts of extract of Khaya senengalansis is measured and is illustrated on Figure 6. The general pace of the trygliceridemy of rabbits for all the amounts is with the fall during all the experiment. However light growth is observed during the $2 \mathrm{~h}$ preceding the beginning of the experiment for the pilot batch and a light growth also for the batch of L25 mg amount, during the hour following the beginning of the experiment.

The variations of the cholesterolemy of rabbits subjected to the various amounts of extracts of Khaya senegalensis according to time, is illustrated on Figure 7. Indeed cholesterolemy of rabbits with tendency to grow the first 15 days of the experiment for every amounts safe for the L0 mg amount of the pilot batch which remains constant. From the 15th days until the end of the experiment the cholesterolemy strongly increases for the amounts L50 mg and L0 mg, and slightly for the L10 mg. Amount while one observes a light fall for the L25 mg amount.

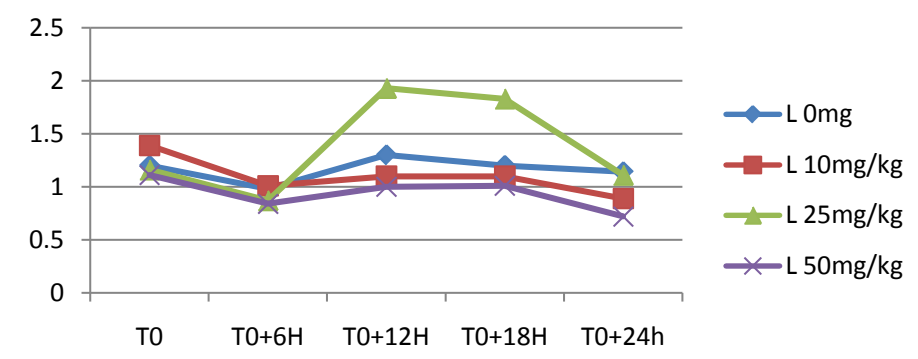

Figure 5. Triglycerides variation under influence of different doses of K.S. in 24 hours.

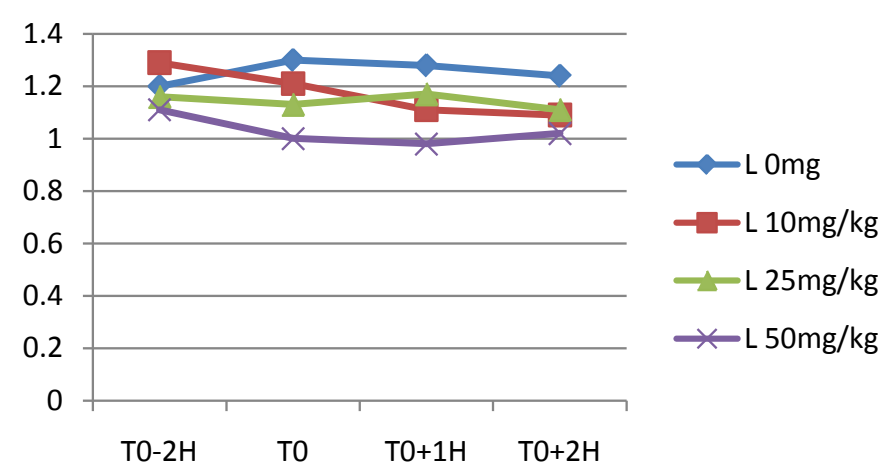

Figure 6. Triglycerides variation under influence of different doses of K.S. in temporary hyperglycemia.

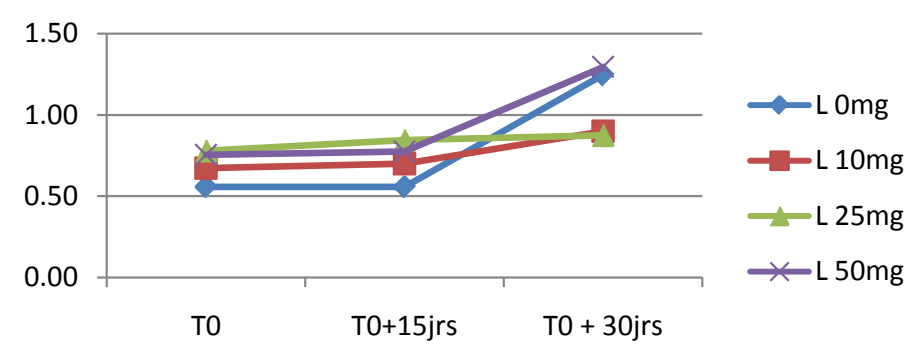

Figure 7. Cholesterol variation under influence of different doses of K.S. versus time. 
The variation of the cholesterolemy of rabbits subjected to the various amounts of extracts of Khaya senegalensis during $24 \mathrm{~h}$, is illustrated on Figure 8. During the first 12 hours of the experiment, the cholesterolemy has a downward trend for all the amounts except the L0 mg amount which grows slightly. Between the 12th and the 18th hour of the experiment the cholesterolemy tends to become relatively constant for all the doses. Finally the measured cholesterolemy falls slightly for all the amounts.

The variation of the cholesterolemy of rabbits in temporary hyperglycemia subjected to the various amounts of extracts of Khaya senegalensis, is illustrated on Figure 9. During the 2 hours previous the experiment, the cholesterolemy has a downward trend for the amounts L10 mg and while L25 mg for the amounts L0 mg and L50 mg which grows slightly. Beginning of the experiment until $2 \mathrm{~h}$ after the beginning of the experiment the measured cholesterolemy falls slightly for all the amounts.

\section{Discussion}

The phytochemical analysis revealed the presence of polyphenolic compounds (tannins, anthocyanins, leuco anthocyanin) of saponins, steroids and anthracene compounds (o-glycosides).

The alcoholic extract of Khaya senegalensis administration for four weeks did not significantly altered the change of body weight of treated rabbits $(\mathrm{p}<0.05)$. Although we have noticed an increase respectively fortnightly from $1.82 \%$ and $6.55 \%, 8.75 \%$ ET17, 25\%, 5\% and 7.75\% for doses of $10 \mathrm{mg} / \mathrm{kg}, 25 \mathrm{mg} / \mathrm{kg}$ and 50 $\mathrm{mg} / \mathrm{kg}$ body weight.

Blood glucose did not change in the rabbits treated de $10 \mathrm{mg} / \mathrm{kg}$ dose of BW extract, 24 hours after administration. For cons, the administration of $25 \mathrm{mg}$ and $50 \mathrm{mg} / \mathrm{kg} \mathrm{BW}$ extract resulted in a decrease of $12.66 \%$, $25.30 \%$ in blood sugar after 24 hours, only the resulting decline in the dose of $50 \mathrm{mg} / \mathrm{kg} \mathrm{BW}$ extract is significant, one could think of a dose-dependency for this effect. This could be justified by the presence in the extract of glycosides which increases hepatic glucose utilization [15], so the o-glycosides, even scarce in the extract could inhibit the gluconeogenesis and suppress insulin in rabbits treated by increasing the rate of membrane glucose transporters such as Al-Achi demonstrated in 2005. The extract may also increase the secretion of insulin via its anti-oxidant activity [16] as terpenes and flavonoids influence pancreatic $\beta$ cells and stimulate insulin secretion by their anti activity oxidizing [6]. Indeed, it would set in motion a closing signal of $\mathrm{K}^{+} / \mathrm{ATP}$, membrane depolarization and stimulation of $\mathrm{Ca}^{2+}$ influx, the first step in insulin secretion [12] [17] showed that ethyl extract of Khaya senegalensis has an anti-radical activity. In fact, our study showed the presence in the extract of an abundant amount of polyphenolic compounds which have an anti-radical activity [18]. Some flavonoids,

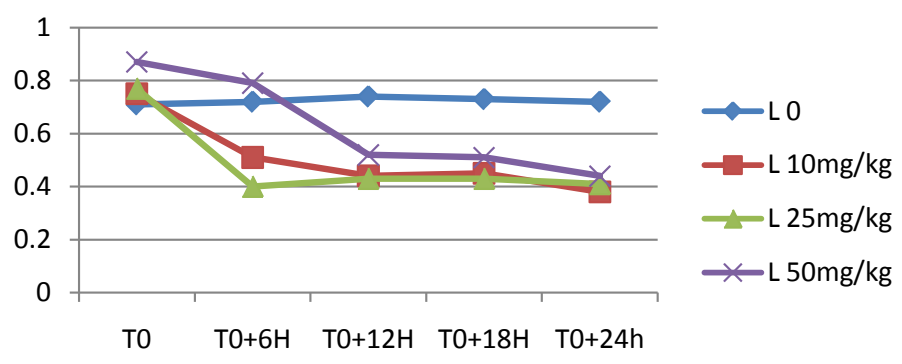

Figure 8. Cholesterol variation under influence of different doses of K.S. in 24 hours.

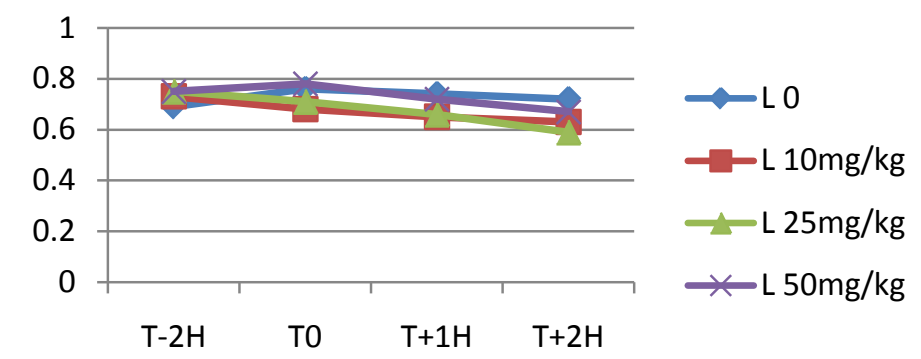

Figure 9. Cholesterol variation under influence of different doses of K.S. in temporary hyperglycemia. 
which have been isolated from plants, inhibit glucose transporters in the intestines, decrease the expression of genes that control gluconeogenesis, increase the storage of glucose in the liver and reduce the breakdown of glycogen , for example, which is a catechin tannin inhibits the intestinal absorption of glucose as well as epicatechin gallate increases hepatic glycogen synthesis and quercetin increases insulin synthesis, it has been reported in the literature that Khaya senegalensis bark are rich in these compounds. It is possible that the hypoglycemic action of the plant is related to the presence of these compounds.

Glucose does not appear to vary significantly ( $>>0.05$ ) after one month of daily administration of 10 - 25 $50 \mathrm{mg} / \mathrm{kg}$ of extract ethyl BW Khaya senegalensis. There is still that daily administration of $50 \mathrm{mg} / \mathrm{kg}$ of BW extract decreased by $25 \%$ glucose test after fifteen days, this decrease is not significant.

The hypoglycemic action of the extract is not very remarkable for rabbits even in overload of glucose, because rabbits are not diabetic and that any variation in blood glucose have been standardized by the regulatory systems this parameter.

For cons, the administration of $25 \mathrm{mg}$ of ethyl extract of Khaya senegalensis causes a decrease of $42.05 \%$ triglyceride 15 days after the start of the test and increased $48.46 \%$ and $52.50 \%$ respectively after $12 \mathrm{~h}, 18 \mathrm{~h}$ and action of the extract. In addition, no significant changes were noted on triglycerides with rabbits temporary hyperglycemia. Also, the statistical analysis of these results has revealed no significant difference.

Similarly, in normoglycemic rabbits treatment with the extract Khaya senegalensis, it was found that after a month trial, the daily administration of the extract ethyl 10 - 25 - 50 mg/kg BW Khaya senegalensis not significant changes in serum cholesterol compared to control group. However, cholesterol levels in normoglycemic rabbits after feeding different doses of ethyl extracts of Khaya senegalensis $24 \mathrm{H}, 6 \mathrm{H}$ shows that after beginning cholesterol decreased $29.17 \%, 44.44 \%,-9.72 \%$, respectively 10 - 25 - $50 \mathrm{mg} / \mathrm{kg}$ doses for BW. This decline was accentuated after $12 \mathrm{~h}$ and password $-9.72 \%$ to $29.73 \%$ for $50 \mathrm{mg} / \mathrm{kg}$ dose, then continues to decline slowly. Statistical analysis of the results showed no significant difference both in rabbits.

Different doses of ethyl extracts of Khaya senegalensis not affect the lipid profile of rabbits (triglycerides and cholesterol) because they are not diabetic. Indeed, insulin deficiency or insulin resistance may be responsible for hyperlipidemia, because insulin has an inhibitory action on the 3-hydroxy-3-methyl-glutaryl coenzyme A reductase (HMG-CoA reductase), a key enzyme for the biosynthesis of cholesterol. On the other hand, glucagon, catecholamines and other hormones increase lipolysis.

Are in the normal physiology of rabbits does not allow a remarkable action of ethyl extract on blood glucose, triglycerides and cholesterol. Thus, rabbits through their regulatory system that works have evacuated the extract and the hypoglycemic effect is more remarkable.

Ethyl bark extract of Khaya senegalensis has an effect on the liver and kidneys of normoglycemic stuffed rabbits for a month. In the liver, hepatocytes are almost normal. However, we note the presence of many cells in the connective tissue of the central vein and dilation space of Disse. This would mean that the ethyl extract of bark of Khaya senegalensis have induced liver cell proliferation that led to an expansion of the space of Disse. Compared to the kidneys, it notes that there are abnormal glomeruli. The renal tubules appeared dilated in places and there are glomeruli being destroyed.

\section{Conclusion}

The results from this study have show that oral daily administration of the ethanolic extract of Khaya senegalensis for lond period has side effect. Therefore, chronic usage of khaya should be avoided.

\section{References}

[1] Musa, H.R., Ambroggi, M., Souto, A. and Angeby, K.A. (2005) Drug Susceptibility Testing of Mycobacterium Tuberculosis by Nitrate Reductase Essay Applied Directly on Microscopy-Positive Sputum Sample. Journal of Clinical Microbiology, 43, 3159-3161. http://dx.doi.org/10.1128/JCM.43.7.3159-3161.2005

[2] Sharma, B., Viswanath, G., Salunke, R. and Roy, P. (2008) Effects of Flavonoid-Rich Extract from Seeds of Eugenia jambolana (L.) on Carbohydrate and Lipid Metabolism in Diabetic Mice. Food Chemistry, 110, 697-705. http://dx.doi.org/10.1016/j.foodchem.2008.02.068

[3] Guermaz, R., Zekri, S., Hatri, A., Kessal, F. and Brouri, M. (2008) Le diabète de type 2 en Algérie: Poids actuel et à venir. La Revue de Médecine Interne, 29, S49-S50. http://dx.doi.org/10.1016/j.revmed.2008.03.087

[4] Singh, J. and Kakkar, P. (2009) Antihyperglycemic and Antioxidant Effect of Berberis aristata Root Extract and Its 
Role in Regulating Carbohydrate Metabolism in Diabetic Lapins. Journal of Ethnopharmacology.

[5] Zhou, I., Zhou, S., Tang, J., Zhang, K., Guang, L., Huang, Y., Xu, Y., Ying, Y., Zhang, L. and Li, D. (2009) Protective Effect of Berberine on Beta Cells in Streptozotocin- and High-Carbohydrate/High-Fat Diet-Induced Diabetic Lapins. European Journal of Pharmacology, 606, 262-268. http://dx.doi.org/10.1016/j.ejphar.2008.12.056

[6] Sarkhail, P., et al. (2007) Antidiabetic Effect of Phlomis anisodonta: Effects on Hepatic Cells Lipid Peroxidation and Antioxidant Enzymes in Experimental Diabetes. Pharmacological Research, 56, 261-266. http://dx.doi.org/10.1016/j.phrs.2007.07.003

[7] Bahorun, T. (1997) Substances naturelles actives: La flore mauricienne, une source d'approvisionnement potentielle. Food and Agricultural Research, 83-94.

[8] Gill, L.S. (1992) Ethnomedical Uses of Plants in Nigeria. Uniben Press, Benin City, 15-65.

[9] Maydell, H.J. (1986) Trees and Shrubs of Sahel-Thier Charactérisatics and Uses. Gesdtschaft, Fur, Germany, 105-110.

[10] Kolawole, S.O., et al. (2011) Effects of Aqueous Extract of Khaya senegalensis Stem Bark on Biochemical and Hematological Parameters in Rats. Journal of Pharmacological and Toxicological Methods, 6, 602-607.

[11] Adebayo, J.O., Yacubu, M.T., Egwin, E.C., Owoyele, V.B. and Enaibe, B.U. (2003) Effect of Ethanolic Extract of Khaya senegalensis on Some Biochemical Parameters of Rat Kidney. Journal of Ethnopharmacology, 88, 69-72. http://dx.doi.org/10.1016/S0378-8741(03)00193-4

[12] Lompo, M., Dubois, J. and Guissou, I.P. (2007) In Vitro Preliminary Study of Free Radical Scavenging Activity of Extracts from Khaya senegalensis A. Juss. Journal of Biological Sciences, 7, 677-680. http://dx.doi.org/10.3923/jbs.2007.677.680

[13] Houghton, P.J. and Raman, A. (1998) Laboratory Handbook for Fractionation of Natural Extracts. Chapman and Hall, London, $199 \mathrm{p}$.

[14] Allain, C.C., Poon, L.S., Chan, C.S., Richmond, W. and Fu, P.C. (1974) Enzymatic Determination of Total Serum Cholesterol. Clinical Chemistry, 20, 470-475.

[15] Al-Achi, A. (2005) Herbs that Affect Blood Glucose Level. Women’s Health in Primary Care, 8, 325-330.

[16] Pari, L. and Venkateswaran, S. (2002) Hypoglycaemic Activity of Scoparia dulcis L. Extract in Alloxan Induced Hyperglycaemic Rats. Phytotherapy Research, 16, 662-664.

[17] Waltner-Law, M.E., Wang, X.L., Law, B.K., Hall, R.K., Nawano, M. and Granner, D.K. (2002) Epigallocatechin Gallate, a Constituent of Green Tea, Represses Hepatic Glucose Production. Journal of Biological Chemistry, 277, 3493334940. http://dx.doi.org/10.1074/jbc.M204672200

[18] Vergès, B. (2007) Physiopathologie de la dyslipidémie du syndrome métabolique et du diabète de type 2. Nutrition Clinique et Métabolisme, 21, 9-16. http://dx.doi.org/10.1016/j.nupar.2007.01.011 
Scientific Research Publishing (SCIRP) is one of the largest Open Access journal publishers. It is currently publishing more than 200 open access, online, peer-reviewed journals covering a wide range of academic disciplines. SCIRP serves the worldwide academic communities and contributes to the progress and application of science with its publication.

Other selected journals from SCIRP are listed as below. Submit your manuscript to us via either submit@scirp.org or Online Submission Portal.
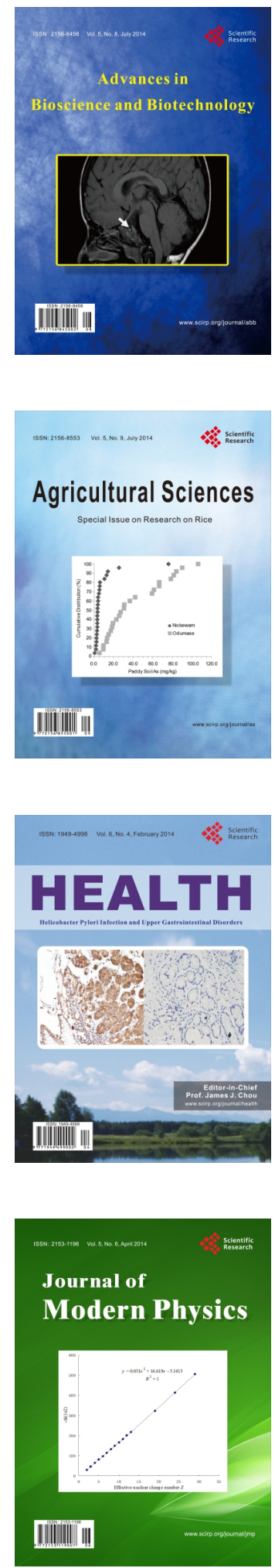
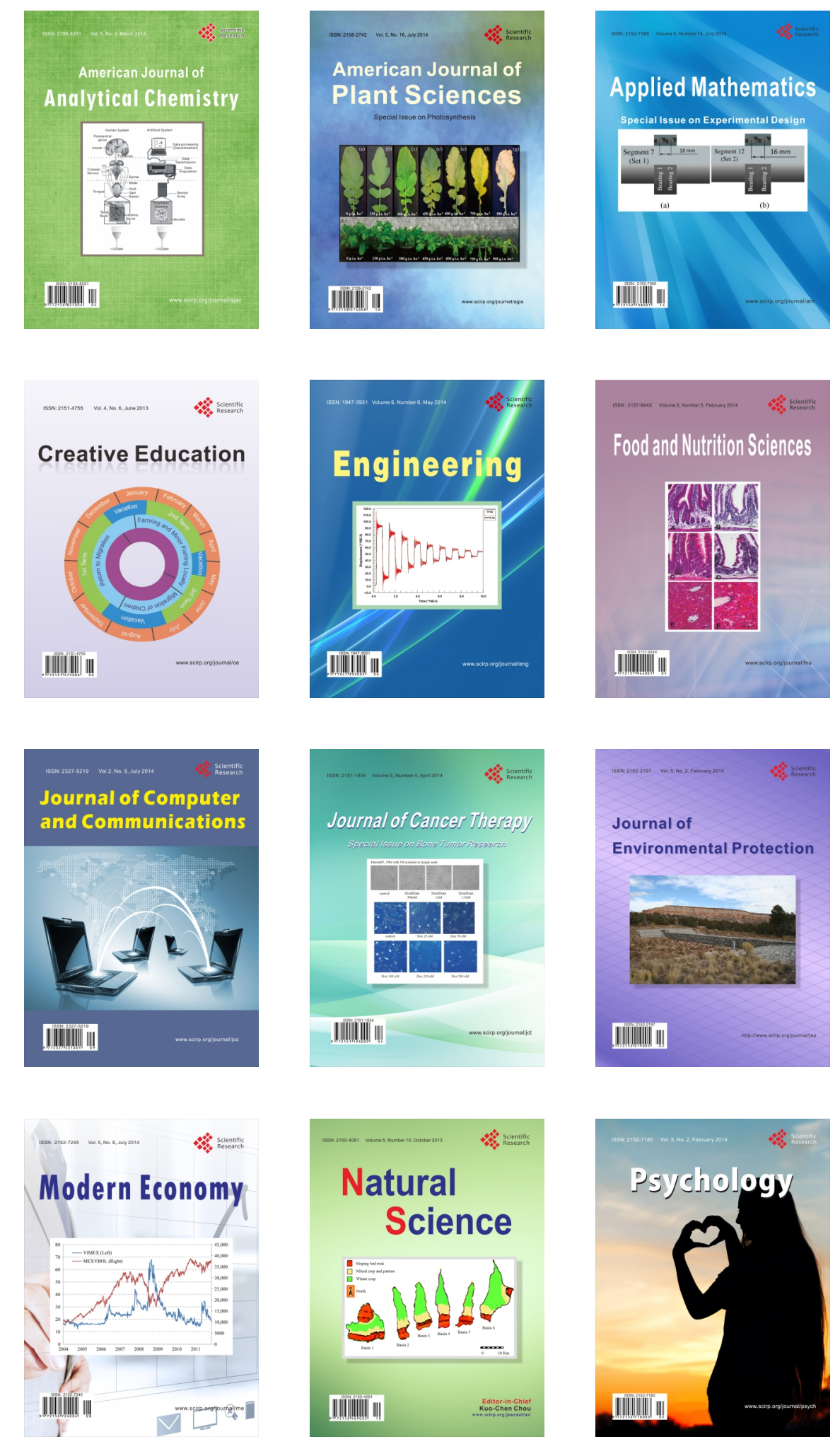